Journal of Bangladesh Academy of Sciences, Vol. 36, No. 2, 213-220, 2012

\title{
ANTIMICROBIAL SUSCEPTIBILITY OF VIBRIO SPECIES ISOLATED FROM BRACKISH WATER SHRIMP CULTURE ENVIRONMENT
}

\author{
M. S. HOSSAIN, M. AKTARUZZAMAN, A. N. M. FAKHRUDDIN*, M. J. UDDIN, \\ S. H. RAHMAN, M. A. Z. CHOWDHURY ${ }^{1}$ AND M. K. ALAM \\ Department of Environmental Sciences, Jahangirnagar University, Savar, Dhaka-1342, \\ Bangladesh
}

\begin{abstract}
A comparative study regarding prevalence and antimicrobial susceptibility of Vibrio species in the black tiger shrimp (Penaeus monodon Fabricius) culture environment as well as market samples were analyzed. Total Vibrio counts were found to range up to $2.5 \times 10^{3} \mathrm{cfu} / \mathrm{gm}$ and $60 \mathrm{cfu} / \mathrm{gm}$ in shrimp and Gher water samples, respectively. Results revealed that the total vibrio count were found to be higher in samples taking from the market shops in Dhaka city than Gher shrimp samples and the live shrimps were not contaminated with Vibrio species but dead shrimps were found contaminated, which were collected from shrimp Gher. In the antimicrobial susceptibility test, highest $28.57 \%$ resistance among total Vibrio isolates was observed to penicillin and cephalexin. Among the seven isolates of Vibrio species from Gher water sample one isolate displayed multi-drug resistance (MDR). The main reason of antibiotic resistance could be the indiscriminate application of antibiotics in shrimp farming and release of shrimp pond effluent to estuarine ecosystems or post harvest contamination of shrimps with the antibiotic resistant bacteria through the environment and human handling.
\end{abstract}

Key words: Food safety, Vibrio species, Penaeus monodon, Prevalence, Antimicrobial resistance, Multiple drug resistance

\section{INTRODUCTION}

Food security is a complex issue, where various factors pose a condition of risk to fish food safety and they range from contamination from the environment where it is caught up to contamination by the consumer before eating (Vieira 1989). Black tiger shrimp may contain many bacteria of public health importance like Vibrio species. Presence of such pathogenic bacteria in shrimp beyond certain limits renders it unfit and dangerous for human consumption. Consumption of raw or undercooked seafood is the factor most commonly associated with infection (Butt et al. 2004).

Shrimps are one of the most important commodities of the global fishery trade (Bhaskar et al. 1995). The shrimp sector is the second largest export earner for Bangladesh. It provides

\footnotetext{
* Corresponding author: <a.fakhruddin2@mail.dcu.ie>.

${ }^{1}$ Agrochemical and Environmental Research Division, Institute of Food and Radiation Biology, Atomic Energy Research Establishment, Savar, Dhaka-1349, Bangladesh.
} 
millions of employment and earns more than USD 428 million annually (FSYB 2007). However, a lot of fishery resources are simply wasted due to lack of appropriate post harvest technology (James 1984).

The development of antimicrobial resistance among pathogenic bacteria has emerged as a major public health concern, which has led to an intensification of discussion about the prudent use of antimicrobial agents, especially in veterinary medicine, nutrition and agriculture (Caprioli et al. 2000). Antimicrobial agents have been applied to the shrimp feed and water in large quantities primarily to treat and prevent diseases in farmed shrimps. Consequently, antimicrobial agents persist in sediment and aquatic environments, leading to deteriorated environmental conditions and conferring antimicrobial resistance to the sediment bacteria. Of particular concern is the indiscriminate use of antibiotics leading to the development of multiple-antibioticresistant pathogenic bacteria in shrimps and humans (Zanetti et al. 2001). In this case, shrimps could serve as delivery vehicles of antimicrobial resistance to pathogenic bacteria from aquatic environments to humans and from one country to another.

The purpose of this investigation was to determine the prevalence of drug resistant Vibrio species in cultured black tiger shrimp and shrimp pond environment. The present study was also attempted to help the surveillance of the antimicrobial resistance status.

\section{MATERIALS AND METHODS}

The black tiger shrimp and Gher water samples were collected from Kaliganj Upazilla in Satkhira district of Bangladesh where most of the shrimp farming is carried out. The study area lies between the latitudes $22^{\circ} 27^{\prime} 34 \mathrm{~N}$ and longitudes $89^{\circ} 01^{\prime} 37 \mathrm{E}$. The samples were collected in July, 2011. Besides these, five shrimp samples were collected from the different markets of Savar and Dhaka city to compare the prevalence of pathogenic bacteria with the shrimp Gher samples. The shrimp samples were collected individually in pre-sterilized polyethylene bags and water samples in pre-sterilized container and brought to the laboratory as soon as possible for the analysis. To avoid further contamination, during transportation from the source to the laboratory, samples were kept in insulated box with ice to maintain the temperature around 4 to $6^{\circ} \mathrm{C}$.

Two hundred fifty gram of shrimp samples were blended aseptically. From the blending portion, $10 \mathrm{gm}$ sample and $90 \mathrm{ml}$ sterile normal saline $(0.9 \% \mathrm{w} / \mathrm{v}, \mathrm{NaCl})$ solution were taken in a conical flask to make a homogenous suspension. Samples were serially diluted and thoroughly mixed using Vortex-mixture and analyzed for microbial content. Thiosulphate citrate bile salt sucrose (TCBS) agar was used for enumeration of total Vibrio bacteria. The TCBS agar has been melted, brought to $45^{\circ} \mathrm{C}$ and was poured into sterile petridishes. After solidifying and inoculation, plates were incubated at $35^{\circ} \mathrm{C}$ for 24 to 48 hours. Distinctive 
yellow and green colonies on agar plates were picked and streaked on new TCBS agar plates several times to purify bacterial isolates until pure cultures of isolates were obtained. Gher water samples were also analyzed in an identical manner.

Bacterial susceptibility to antimicrobial agents was performed by the disk diffusion method using guidelines established by Bauer et al. (1966). A total of 12 antibiotic discs (Oxoid Ltd., Basingstoke, Hampshire, UK) comprising of streptomycin $10 \mu \mathrm{g}$, erythromycin $15 \mu \mathrm{g}$, chloramphenicol $30 \mu \mathrm{g}$, ciprofloxacin $5 \mu \mathrm{g}$, penicillin $10 \mu \mathrm{g}$, norfloxacin $10 \mu \mathrm{g}$, ampicillin $10 \mu \mathrm{g}$, kanamycin $30 \mu \mathrm{g}$, amoxicillin $10 \mu \mathrm{g}$, azithromycin $15 \mu \mathrm{g}$, cephalexim $30 \mu \mathrm{g}$ and sulphamethoxazole $25 \mu \mathrm{g}$ were used. Within $15 \mathrm{~min}$ of the application of the discs, the plates were inverted and incubated at $37^{\circ} \mathrm{C}$. After $16-18 \mathrm{hr}$ of incubation, the plates were examined, and the diameters of the zones of complete inhibition to the nearest whole millimeter were measured. The zone diameter for individual antimicrobial agents was then translated into susceptible, intermediate and resistant categories according to the interpretation table of the Oxoid Ltd., Basingstoke, UK. Based on the occurrence of resistance to more than three drugs, the isolates of each sampling sites were grouped as multiple drug resistant isolates (Manjusha et al. 2005).

\section{RESULTS AND DISCUSSION}

A total of seven mixed samples of the black tiger shrimps and six water samples collected from Gher water have been analyzed. Fig. 1 illustrates the total Vibrio count (TVC) of different shrimp and water samples. The TVC ranged up to $2.5 \times 10^{3} \mathrm{cfu} / \mathrm{gm}$ in samples and $60 \mathrm{cfu} / \mathrm{ml}$ in shrimp and water samples, respectively.

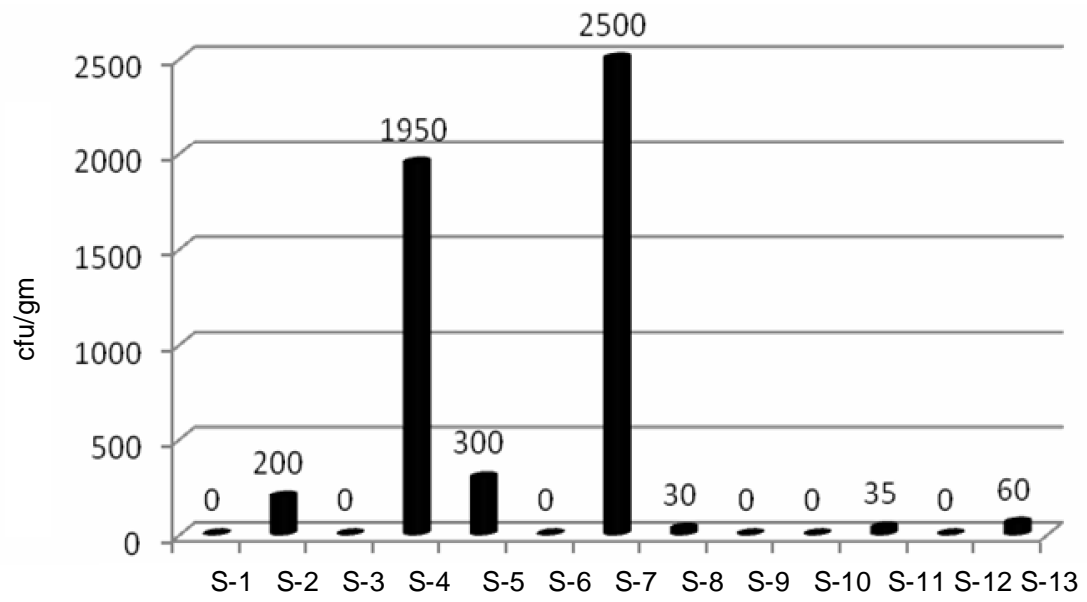

Fig. 1. Total Vibrio count in shrimp and water samples (S-1 to $S-13)$ collected from Gher water. S-1(live shrimps from Gher), S-2 (dead shrimps from Gher), S-3, S4, S-5, S-6, S-7 (market shrimp), S-8, 9, S-10, S-11, S-12, S-13 (shrimp Gher water samples). 
Gher shrimp samples were less contaminated compared to the market samples. Areerat et al. (1999) reported that Vibrio species levels from harvested shrimps ranged between $1.30 \times 10^{3}$ and $1.44 \times 10^{5}$, which is similar to the finding of the present study. This organism has been found to be autochthonous to marine (Mathew et al. 1988) and brackish water systems (Blake et al. 1980). Vibrio species have been found to be associated with pond mud, water and shrimp samples analysed in Thailand (Leangphibul et al. 1986), and in India (Bhaskar and Setty 1994). The major sources of this Vibrio species in samples of shrimp may be sediment, water and feeds. Vibrio species was present in dead shrimp samples and absent in live shrimp samples collected from Gher. This result suggests that the death of shrimps may be due to the presence of Vibrio species. This result also reveals that the concerned black tiger shrimp had an exposure to very unhygienic condition of different stages. Indiscriminate disposal of organic wastes including sewage waste, household wastes, rotten food stuff, feces, remaining parts of the body of dead organisms are responsible for such pollution. Besides them, surface run off, rainwater percolation, flood, storm and other natural disasters contaminate the water of Gher.

Table 1. Diameter of zone of inhibition (in $\mathrm{mm}$ ) of selected isolates with different antibiotics discs.

\begin{tabular}{|c|c|c|c|c|c|c|c|}
\hline \multirow{4}{*}{ Antibiotic discs } & \multicolumn{7}{|c|}{ Mean diameter of the zone of inhibition $(\mathrm{mm})$ of selected isolates } \\
\hline & \multicolumn{7}{|c|}{ Vibrio sp. isolates } \\
\hline & $\mathrm{V}_{1}$ & $\mathrm{~V}_{2}$ & $\mathrm{~V}_{3}$ & $\mathrm{~V}_{4}$ & $\mathrm{~V}_{5}$ & $\mathrm{~V}_{6}$ & $\mathrm{~V}_{7}$ \\
\hline & $\mathrm{S}$ & $\mathrm{S}$ & $\mathrm{S}$ & W & W & $\mathrm{w}$ & W \\
\hline \multicolumn{8}{|c|}{ Group I- Inhibitors of cell wall synthesis } \\
\hline Amoxycillin $(10 \mu \mathrm{g})$ & 16 & 23 & 21 & 23 & 29 & 25 & 9 \\
\hline Penicillin $(10 \mu \mathrm{g})$ & 11 & 21 & 19 & 15 & 29 & 21 & 0 \\
\hline Ampicillin $(10 \mu \mathrm{g})$ & 17 & 22 & 24 & 20 & 27 & 24 & 11 \\
\hline Cephalexin $(30 \mu \mathrm{g})$ & 18 & 15 & 15 & 14 & 21 & 18 & 0 \\
\hline \multicolumn{8}{|c|}{ Group II - Inhibitors of protein synthesis } \\
\hline Kanamycin $(30 \mu \mathrm{g})$ & 21 & 19 & 24 & 19 & 25 & 21 & 21 \\
\hline Erythromycin $(15 \mu \mathrm{g})$ & 15 & 29 & 29 & 23 & 27 & 29 & 21 \\
\hline Azithromycin $(15 \mu \mathrm{g})$ & 28 & 33 & 27 & 13 & 31 & 31 & 26 \\
\hline Chloramphenicol $(30 \mu \mathrm{g})$ & 25 & 29 & 29 & 34 & 35 & 34 & 29 \\
\hline Streptomycin $(10 \mu \mathrm{g})$ & 19 & 18 & 21 & 19 & 29 & 19 & 18 \\
\hline \multicolumn{8}{|c|}{ Group III - Inhibitors of nucleic acid synthesis } \\
\hline Norfloxacin $(10 \mu \mathrm{g})$ & 32 & 32 & 31 & 29 & 26 & 29 & 29 \\
\hline Sulphamethoxazole $(25 \mu \mathrm{g})$ & 29 & 35 & 24 & 28 & 29 & 27 & 25 \\
\hline Ciprofloxacin $(5 \mu \mathrm{g})$ & 35 & 39 & 35 & 31 & 31 & 25 & 31 \\
\hline
\end{tabular}

$* \mathrm{~S}=$ shrimp, $\mathrm{W}=$ water, $\mathrm{V}=$ Vibrio isolate.

Seven isolates of Vibrio species from shrimp and shrimp Gher water were selected and tested against 12 commonly used antibiotics of three categories. Typically, the raw 
data were interpreted based on the available CLSI (Clinical and Laboratory Standards Institute) data and zone diameter interpretive standards. Table 1 shows the mean diameter of the zone of inhibition $(\mathrm{mm})$ of selected isolates and Fig. 2 summerizes the antimicrobial resistance in Vibrio species isolated from shrimp and their environment. Though antibiotic uses have its advantages, the intensive and extensive uses of antibiotics have led to the emergence of antimicrobial resistance. There is necessity of coordination between human, veterinarian and environmental sectors to clarify the occurrence of resistant pathogens in humans, animals and in the environment (Anon. 2002).

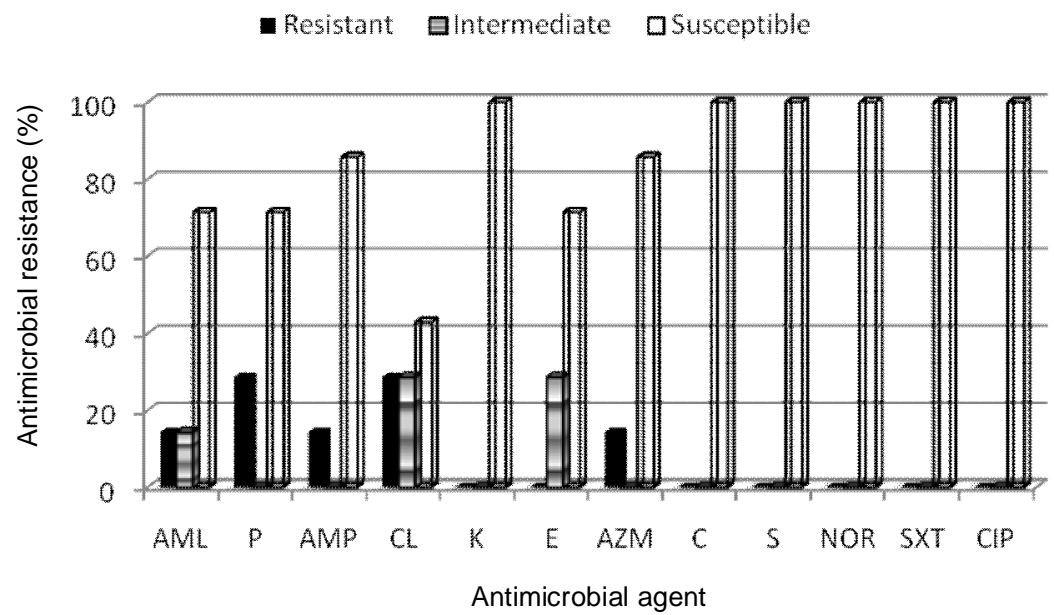

Fig. 2. Antimicrobial resistance in Vibrio species isolated from shrimp and their environment. symbols: AML - amoxycillin, P - penicillin, AMP - ampicillin, CL - cephalexin, K kanamycin, E - erythromycin, AZM - azithromycin, C - chloramphenicol, S streptomycin, NOR - norfloxacin, SXT - sulfamethoxazole, CIP - ciprofloxacin.

Table 2 shows the percentage of isolates which are resistant, intermediate and sensitive to different tested antibiotics. In this study, the highest $(28.57 \%)$ resistance among total Vibrio spp. was observed to penicillin (P) and cephalexin (CL), and no isolates were found resistant to kanamycin $(\mathrm{K})$, erythromycin $(\mathrm{E})$, chloramphenicol $(\mathrm{C})$, azithromycin (AZM), streptomycin (S), norfloxacin (NOR), sulphamethoxazole (SXT), and ciprofloxacin (CIP). All of the tested Vibrio spp. isolates were sensitive to kanamycin (K), chloramphenicol (C), azithromycin (AZM), streptomycin (S), norfloxacin (NOR), sulphamethoxazole (SXT), and ciprofloxacin (CIP) and $42.86 \%$ isolates were sensitive to cephalexin (CL). Table 2 summarizes antibiotic resistance patterns and multiple drug resistance (more than three antibiotics) results in selected Vibrio isolates from shrimps and gher water. Among seven isolates of the total Vibrio spp., 1 from gher water sample displayed multidrug resistance (MDR) of more than three antibiotics. Highest number of resistant antibiotics (AML-P-AMP-CL) was observed to the isolate selected from gher 
water sample. In contrast to the present findings, Adeleye et al. (2008) reported that resistance to $10,9,8$ drugs occurred in the majority of the Vibrio isolates from seafood.

Table 2. Antibiotic resistance profiles for Vibrio species isolated from shrimp and shrimp Gher water.

\begin{tabular}{|c|c|c|c|c|c|c|}
\hline \multirow{2}{*}{$\begin{array}{l}\text { No. of resistant } \\
\text { antimicrobes }\end{array}$} & \multirow{2}{*}{$\begin{array}{l}\text { No. of } \\
\text { isolates }\end{array}$} & \multirow{2}{*}{$\begin{array}{l}\text { Antimicrobial } \\
\text { resistance profiles }\end{array}$} & \multirow[b]{2}{*}{$\%$} & \multicolumn{2}{|c|}{ Origin of isolates } & \multirow{2}{*}{$\begin{array}{c}\text { Resistance } \\
\text { classification }\end{array}$} \\
\hline & & & & Shrimp & $\begin{array}{l}\text { Gher } \\
\text { water }\end{array}$ & \\
\hline 4 & 1 & AML-P-AMP-CL & 14.29 & 0 & 1 & MDR \\
\hline 2 & 1 & CL-AZM & 14.29 & 0 & 1 & NMDR \\
\hline 1 & 1 & $\mathrm{P}$ & 14.29 & 1 & 0 & NMDR \\
\hline 0 & 4 & - & 57.14 & 2 & 2 & NMDR \\
\hline Total & 7 & & 100.00 & 3 & 4 & \\
\hline
\end{tabular}

*MDR - Multiple drug resistance, NMDR - Non multiple drug resistance.

Ferrini et al. (2008) reported that $82 \%$ of Vibrio isolated from fish settings as well as both local and imported seafood showed resistance to ampicillin. In a previous study on potentially pathogenic vibrios isolated from seafood, Ottaviani et al. (2001) also found that those bacteria were sensitive to chloramphenicol ( $90 \%$ of the total), sulfamethoxazole, and ciprofloxacin; conversely, they were also resistant to ampicillin, penicillin, amoxicillin, and cephalexin. Bacterial resistance to ampicillin was most frequently detected among Vibrio species isolated from fishery products (Akinbowale et al. 2006) as well as from a shrimp hatchery (Hameed et al. 2003) and shrimp farms (Vaseeharan et al. 2005). Khan et al. (2002) reported that $100 \%$ isolates of enteropathogenic Vibrio species. from shrimp in Bangladesh were found to show resistance to erythromycin, penicillin, ampicillin, and kanamycin, and 70 and $80 \%$ resistance, respectively to cephalexin and streptomycin. The main reason of antibiotic resistance of pathogenic bacteria may be the application of antibiotics in shrimp farming and release of shrimp pond effluent to estuarine ecosystems or post harvest contamination of shrimps with the antibiotic resistant bacteria through the environment and human handling. In general, bacteria can develop resistance for antibiotics, which share similar genetic structures (Angela et al. 2006). Van de Boogard and Stobberingh (2000), reported that due to indiscriminate use of antimicrobial agents, such high incidence of multi-drug resistance may apparently be occurred which may ultimately replace the drug sensitive microorganisms from antibiotic saturated environment. Rapid urbanization, over-crowding and poor sanitation systems greatly facilitate the greater spread of various diseases in Bangladesh. This growing pace of infections is responsible for an increased use and sometimes abuse of antibiotics.

The results revealed that the shrimp might die during cultivation due to the presence of Vibrio sp., as these were found to be present in dead shrimp samples and absent in live 
shrimp samples collected from the Gher. Market samples were more contaminated with Vibrio sp. compared to the samples collected from Gher samples. In the present study, among the seven selected isolates, one isolate displayed multi-drug resistance to more than three antibiotics. The incidence of Vibrio species in shrimps and their drug resistance pattern in this study demands immediate need for paying attention in this area.

\section{ACKNOWLEDGEMENTS}

This project was financially supported by the Ministry of Science and Information \& Communication Technology, Bangladesh.

\section{REFERENCES}

Adeleye, A., V. Eyinnia, R. Nwanze, S. Smith and E. Omonigbehin. 2008. Antimicrobial susceptibility of potentially pathogenic halophilic Vibrio isolated from seafoods in Lagos, Nigeria. American J. Agric. Biol. Chem. 7: 3791-3794.

Akinbowale, O. H., H. Peng and M. D. Barton. 2006. Antimicrobial resistance in bacteria isolated from aquaculture sources in Australia. J. Appl. Microbiol. 100: 1103-1113.

Angela, L. B., B. B. Ian and S. A. Diana. 2006. Evaluating the vulnerability of surface waters to antibiotic contamination from varying wastewater treatment plant discharges. Environ. Pollut. 142: 295-302.

Anon, 2002. Council recommendation of 15 November, 2001 on the prudent use of antimicrobial agents in human medicine. Off. J. European Comm. L34: 13-16.

Areerat, S., C. Limsuwan, P. Chanratchakool and T. Somsiri. 1999. Bacterial levels in the muscle of post harvested shrimp. Asian Fish. Sci. 12: 357-360.

Bauer, A. W., W. M. M. Kirly, J. C. Sherris and M. Turck. 1966. Antibiotic susceptibility testing by a standardized single disk method. American J. Clin. Pathol. 45: 493-496.

Bhaskar, N. and T. M. R. Setty. 1994. Incidence of vibrios of public health significance in the farming phase of tiger shrimp Penaeus monodon. J. Sci. Food Agric. 66: 225-231.

Bhaskar, N., T. M. R. Setty, G. V. S. Reddy, Y. B. Manoj, C. S. Anantha, B. S. Raghunath and M. A. Joseph. 1995. Incidence of Salmonella in cultured shrimp Penaeus monodon. Aquaculture 138: $257-266$.

Blake, P. A., R. E. Weaver and D. E. Hollis. 1980. Diseases of humans other than cholerae caused by vibrios. Ann. Rev. Microbiol. 34: 341-367.

Butt, A. A., K. E. Aldridge and C. V. Sanders. 2004. Infections related to the ingestion of seafood Part I: viral and bacterial infections. The Lancet Infect. Dis. 4: 201-212.

Caprioli, A., L. Busani, J. L. Martel and R. Helmuth. 2000. Monitoring of antibiotic resistance in bacteria of animal origin: epidemiological and microbiological methodologies. Int. J. Antimicrob. Agents 14: 295-301.

Ferrini A. M., V. Mannoni, E. Suffredini, L. Cozzi and L. Croci. 2008. Evaluation of antibacterial resistance in Vibrio strains isolated from imported seafood and Italian aquaculture settings. Food Anal. Meth. 1: 64-170.

FSYB, 2007. Fishery Statistical Yearbook of Bangladesh. 24th Edition, Fisheries Resources Survey System, Department of Fisheries, Ministry of Fisheries and Livestock. 
Hameed A. S. S., K. H. Rahaman, A. Alagan and K. Yoganandhan. 2003. Antibiotic resistance in bacteria isolated from hatchery-reared larvae and post-larvae of Macrobrachium rosenbergii. Aquaculture 217: 39-48.

James, D. 1984. The future of fish in nutrition. In: INFOFISH Marketing Digest. 4: 41-44.

Khan, A., S. C. Das, T. Ramamurthy and A. Sikander. 2002. Antibiotic Resistance, Virulence Gene, and Molecular profile of Shiga Toxin-Producing Escherichia coli Isolates from Diverse Source in Calcutta, India. J. Cli. Microbiol. 40: 2009-2015.

Leangphibul, P., C. Nilakul, C. Soranchai, S. Tantimavanich and K. Kasemsuksakul. 1986. Investigation of pathogenic bacteria from shrimp farms. Kasetsart J. 20: 333-337.

Manjusha, S., G. B. Sarita, K. K. Elyas and M. Chandrasekaran. 2005. Multiple Antibiotic Resistances of Vibrio Isolates from Coastal and Brackish Water Areas. American J. Biochem. Biotechnol. 1: 201-206.

Mathew, S., I. Karunasagar, G. M. Rao and I. Karunasagar. 1988. Vibrio cholerae in seafoods and environs of Mangalore, India. Asian Fish. Sci. 2: 121-126.

Ottaviani D., I. Bacchiocchi, L. Masini, F. Leoni, A. Carraturo, Giammariolim and G. Sbaraglia. 2001. Antimicrobial susceptibility of potentially pathogenic halophilic vibrios isolated from seafood. Int.J. Antimicrob. Agents 18: 135-140.

Van de Boogard, A. E. and E. E. Stobberingh. 2000. Epidemiology of resistance to antibiotics links between animals and humans. Int. J. Antimicrob. Agents 14: 327-335.

Vaseeharan B., P. Ramasamy, T. Murugan and J. C. Chen. 2005. In vitro susceptibility of antibiotics against Vibrio spp. and aeromonas spp. isolated from Penaeus monodon hatcheries and ponds. Int. J. Antimicrob. Agents 26: 285-291.

Vieira, R. H. S. F. 1989. Aspectos microbiológicos de pescado antese depois de processado. In: Fonteles Filho, A. A.; Vieira, R. H .S .F. Ciênciae tecnologia de produtos pesqueiros. Saint John's (Canadá): MUN Printing Services 1: 1222-1272.

Zanetti, S., T. Spanu, A. Deriu, L. Romano, L. A. Sechi and G. Fadda. 2001. In vitro susceptibility of Vibrio spp. isolated from the environment. Int. J. Antimicrob. Agents 17: 407-409. 